
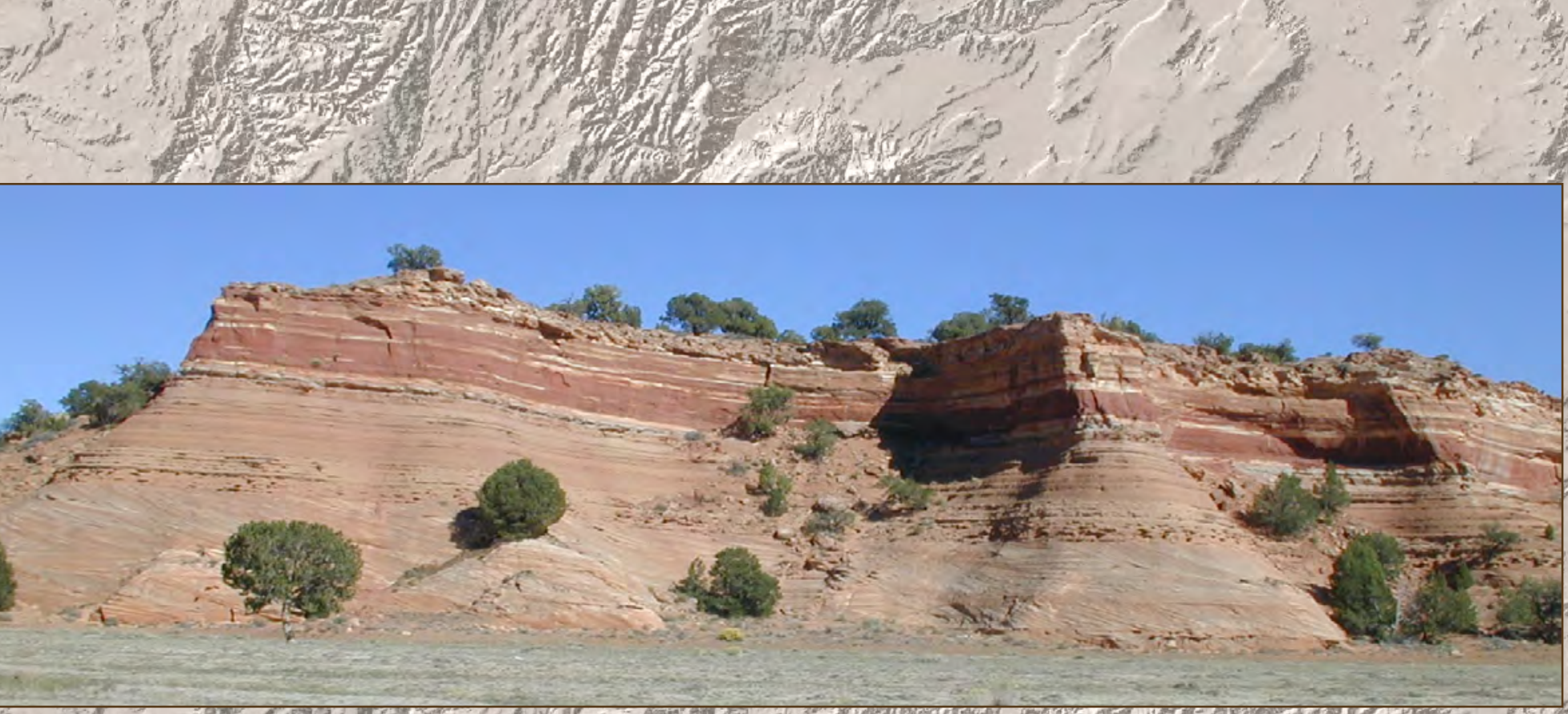

Pla
Prepared in cooperation with the BUREAU OF INDIAN AFFAIRS

\title{
Lithology and Thickness of the Carmel Formation as Related to Leakage Between the D and N Aquifers, Black Mesa, Arizona
}

Scientific Investigations Report 2005-5187

U.S. Department of the Interior U.S. Geological Survey
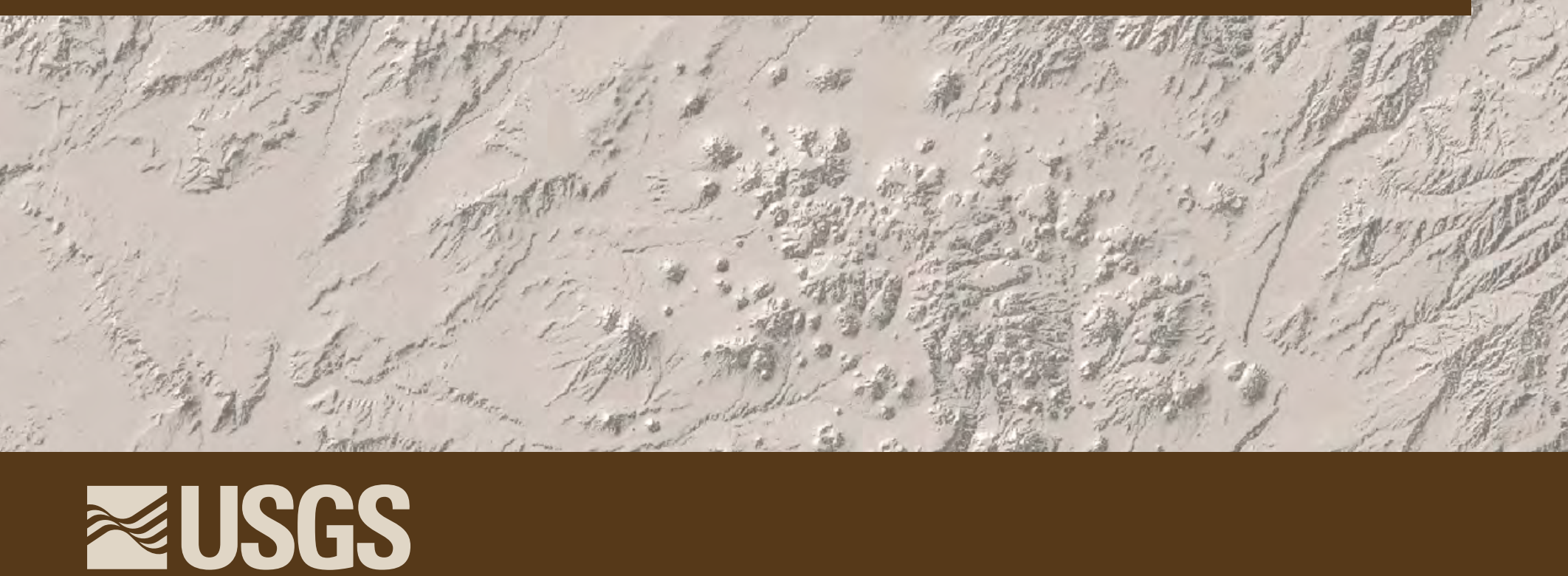


\section{Lithology and Thickness of the Carmel Formation as Related to Leakage Between the $D$ and $N$ Aquifers, Black Mesa, Arizona}

By Margot Truini and J.P. Macy

Prepared in cooperation with the

BUREAU OF INDIAN AFFAIRS

Scientific Investigations Report 2005-5187 


\title{
U.S. Department of the Interior \\ Gale A. Norton, Secretary
}

\section{U.S. Geological Survey \\ P. Patrick Leahy, Acting Director}

\author{
U.S. Geological Survey, Reston, Virginia: 2006 \\ Prepared in the Arizona Water Science Center
}

For product and ordering information:

World Wide Web: http://www.usgs.gov/pubprod

Telephone: 1-888-ASK-USGS

For more information on the USGS--the Federal source for science about the Earth, its natural and living resources, natural hazards, and the environment:

World Wide Web: http://www.usgs.gov

Telephone: 1-888-ASK-USGS

Any use of trade, product, or firm names is for descriptive purposes only and does not imply endorsement by the U.S. Government.

\footnotetext{
Suggested citation:

Truini, Margot, and Macy, J.P., 2006, Lithology and thickness of the Carmel Formation as related to leakage between the D and N aquifers, Black Mesa, Arizona: U.S. Geological Survey Scientific Investigations Report 2005-5187, 7 p., $1 \mathrm{pl}$.
} 


\section{Contents}

Abstract
Introduction.
Purpose and Scope
Hydrogeologic Setting
Study Methods
Geophysical Logs
Silling Logs

\section{Plate}

[In pocket at back of report]

1. Hydrogeologic sections showing correlations of units of the $D$ and $N$ aquifers from borehole-geophysical data and lithologic descriptions, Black Mesa, Arizona

\section{Figures}

1. Locations of study area, traces of hydrogeologic sections, and area where ground-water leakage between the $\mathrm{D}$ and $\mathrm{N}$ aquifers was detected in the southern part of Black Mesa, Arizona, by Lopes and Hoffmann (1997)...

2. Rock formations and hydrogeologic units of the $D$ and $N$ aquifers, Black Mesa, Arizona

3. Thickness of the Carmel Formation, ranges of natural gamma and electrical conductivity from borehole-geophysical logs, and relative ${ }^{87} \mathrm{Sr} /{ }^{86} \mathrm{Sr}$ signatures, Black Mesa, Arizona

\section{Conversion Factors and Datums}

\begin{tabular}{|c|c|c|}
\hline Multiply & By & To obtain \\
\hline inch (in.) & 2.54 & centimeter $(\mathrm{cm})$ \\
\hline inch (in.) & 25.4 & millimeter (mm) \\
\hline foot (ft) & 0.3048 & meter $(\mathrm{m})$ \\
\hline mile (mi) & 1.609 & kilometer $(\mathrm{km})$ \\
\hline square mile $\left(\mathrm{mi}^{2}\right)$ & 2.590 & square kilometer $\left(\mathrm{km}^{2}\right)$ \\
\hline
\end{tabular}

Concentrations of chemical constituents in water are given in milligrams per liter (mg/L).

Vertical coordinate information is referenced to the National Geodetic Vertical Datum of 1929 (NGVD 29).

Horizontal coordinate information is referenced to the North American Datum of 1927 (NAD 27). 


\title{
Lithology and Thickness of the Carmel Formation as Related to Leakage Between the D and N Aquifers, Black Mesa, Arizona
}

\author{
By Margot Truini and J.P. Macy
}

\begin{abstract}
The Carmel Formation is considered the confining unit between the $\mathrm{D}$ aquifer and the underlying $\mathrm{N}$ aquifer on Black Mesa, Arizona. Leakage of ground water from the D aquifer into the $\mathrm{N}$ aquifer, however, has been detected in the southern part of Black Mesa in recent geochemical studies. In this investigation, borehole-geophysical data and lithologic descriptions from drilling logs were used to relate the thickness and lithology of the Carmel Formation to groundwater leakage in the southern part of Black Mesa. This area of leakage corresponds to the area where the Carmel generally is 120 feet thick or less. The formation is likely a sandy siltstone where leakage has been detected and a clayey siltstone in areas where leakage has not been detected.
\end{abstract}

\section{Introduction}

The Carmel Formation, as described by various investigators, consists of a series of sandstone beds separated by siltstone beds and is the confining unit between the $\mathrm{D}$ aquifer and the underlying $\mathrm{N}$ aquifer on Black Mesa in northeastern Arizona. Ground-water leakage from the D aquifer through the Carmel Formation to the $\mathrm{N}$ aquifer has been occurring naturally for thousands of years (Lopes and Hoffmann, 1997; Truini and Longsworth, 2003; fig. 1). The Navajo Nation and the Hopi Tribe are concerned about induced ground-water leakage from the $\mathrm{D}$ aquifer resulting from industrial and municipal pumping of water from the $\mathrm{N}$ aquifer (Truini and Longsworth, 2003). Leakage is a concern because $\mathrm{D}$ aquifer water, which is used primarily for agricultural and livestock purposes, typically has concentrations of dissolved solids between 500 and $1,000 \mathrm{mg} / \mathrm{L}$, exceeding the U.S. Environmental Protection Agency Secondary Drinking Water Regulation of $500 \mathrm{mg} / \mathrm{L}$ (U.S. Environmental Protection Agency, 2005). Ground water in the $\mathrm{N}$ aquifer, which is the main source of municipal water for the Navajo Nation and the Hopi Tribe, has concentrations of dissolved solids less than $500 \mathrm{mg} / \mathrm{L}$.

Initial studies addressing leakage from the D aquifer to the N aquifer by Lopes and Hoffmann (1997) and GeoTrans Inc. (1993) suggest that leakage is most predominant in areas where, according to Harshbarger and others (1957), the Carmel Formation consists primarily of sandstone layers rather than siltstone layers. Lopes and Hoffmann (1997) delineated a leakage boundary that extends from northeast of Rough Rock in a roughly southwesterly direction to Second Mesa in the confined part of the $\mathrm{N}$ aquifer (fig. 1). Truini and Longsworth (2003) completed a hydrogeologic characterization of the D aquifer to determine ground-water movement and geochemical signatures in relation to leakage. On the basis of strontiumisotope ratios, they determined that leakage occurs in zones north and south of the leakage boundary.

The Bureau of Indian Affairs (BIA) recognized the hydrogeologic significance of the Carmel Formation in water-supply issues for Black Mesa, and in 2001 the U.S. Geological Survey, in cooperation with the BIA, began a program to evaluate the lithology and thickness of the Carmel in relation to leakage. The study area covers about 3,300 $\mathrm{mi}^{2}$ on Black Mesa, including parts of the Navajo and Hopi Indian Reservations.

\section{Purpose and Scope}

The purpose of this report is to describe the lithology and thickness of the Carmel Formation in relation to known areas of ground-water leakage in the confined area of the $\mathrm{N}$ aquifer underlying Black Mesa, Arizona. The report describes the Carmel Formation on the basis of available boreholegeophysical logs and lithologic descriptions from drilling logs. 


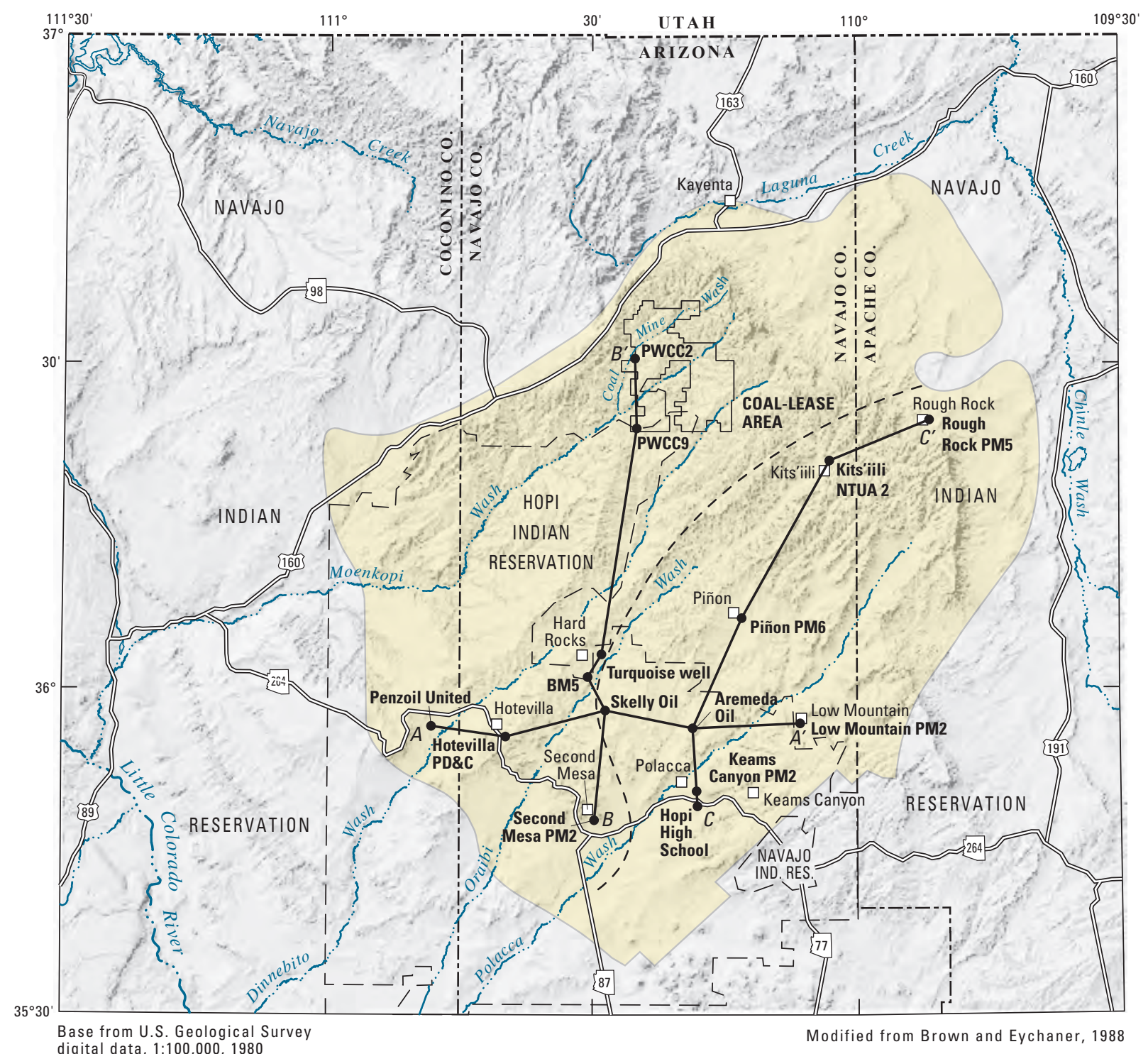

digital data, 1:100,000, 1980

Lambert Conformal Conic projection

Standard parallels $29^{\circ} 30^{\prime}$ and $45^{\circ} 30^{\prime}$

central meridian $-111^{\circ} 30^{\prime}$
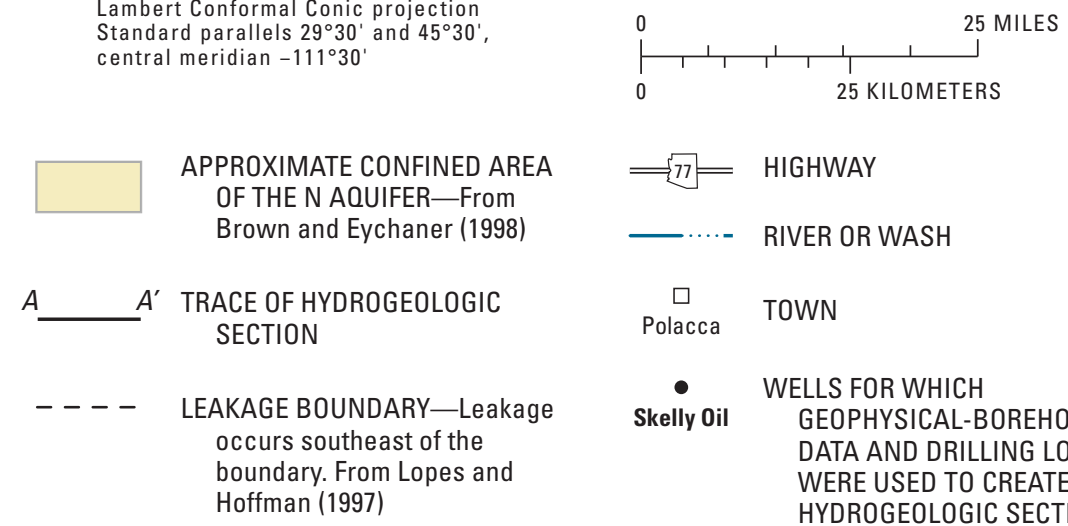
—77 $=$ HIGHWAY
- ...- RIVER OR WASH
$\square$
Polacca
- WELLS FOR WHICH
Skelly 0il GEOPHYSICAL-BOREHOLE
DATA AND DRILLING LOGS
WERE USED TO CREATE
HYDROGEOLOGIC SECTIONS

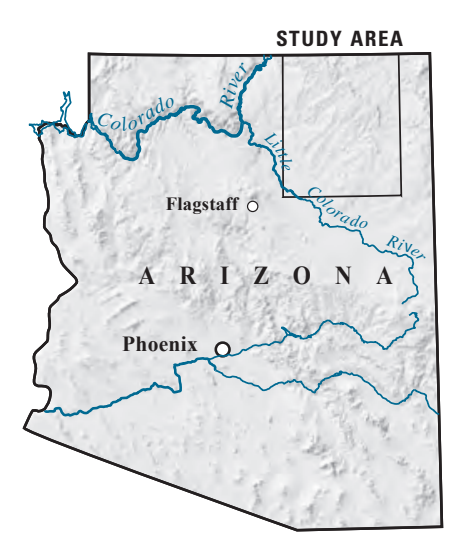

Figure 1. Locations of study area, traces of hydrogeologic sections, and area where ground-water leakage between the $\mathrm{D}$ and $\mathrm{N}$ aquifers was detected in the southern part of Black Mesa, Arizona, by Lopes and Hoffmann (1997). 


\section{Hydrogeologic Setting}

Black Mesa is a large moderately dissected highland in northeastern Arizona. The Black Mesa Basin, a geologic basin named after this highland area, contains several thousand feet of sediments accumulated from Cambrian to Tertiary time. Deposition attendant to marine advances and retreats produced complex intertonguing lithologic units that contain abrupt facies changes. The Black Mesa Basin was deformed during the Late Cretaceous uplift, but less so in comparison to the rest of the Colorado Plateau. The resultant deformation of pre-Cretaceous flat-lying sandstones, siltstones, and claystones induced folds and faults that helped to form sedimentary facies variations that established some of the principal controls on the occurrence and movement of ground water in the study area (Cooley and others, 1969).

Two aquifers have been delineated among the sedimentary sequence of Jurassic to Cretaceous age (Cooley and others, 1969). The D aquifer is named for the primary water-bearing unit, the Dakota Sandstone, and also includes the Morrison Formation, the Entrada Sandstone, and in the southeastern part of the study area, the Carmel Formation (fig. 2). The $\mathrm{N}$ aquifer is named for the principal water-bearing unit, the Navajo Sandstone, and includes other formations from the Glen Canyon Group: the Kayenta Formation, the Moenave Formation, and the Wingate Sandstone (Cooley and others, 1969; Dubiel, 1989; Blakey, 1989; fig. 2).

The Carmel Formation, which unconformably overlies the Navajo Sandstone, was described by Harshbarger and others (1957) as a series of red and white sandy-siltstone beds and sandstone beds. The Carmel Formation has five members: the Upper Member, the Winsor Member, the Paria River Member, the Crystal Creek Member, and the Judd Hollow Member (Jenney and Reynolds, 1989). The Judd Hollow Member is the only member that likely is present in the study area and was deposited in a low energy subtidal coastal-plain environment in northwestern Arizona and southern Utah (Vorrheese, 1978; Geeseman, 1979).

\section{Acknowledgements}

The authors thank the staff of the BIA, the Navajo Department of Water Resources, and the Navajo Tribal Utility Authority who provided assistance on the Navajo Indian Reservation where necessary. Staff of Peabody Western Coal Company provided access to lithologic information for company wells.

\section{Study Methods}

Borehole-geophysical logs and descriptions from well cuttings were used to determine the presence, thickness, and lithology of the Carmel Formation. Information derived from the geophysical and drilling logs were related to ground-water leakage in the Black Mesa study area. Natural-gamma and electromagnetic-induction logs were used to determine the general lithology, thickness, and depth below land surface of geologic units; driller and geologic descriptions of drilling logs were used as a record of the geologic units and the relative water levels within the $\mathrm{D}$ and $\mathrm{N}$ aquifers, and to support the borehole-geophysical data.

\section{Geophysical Logs}

Natural-gamma logs are records of the amount of natural-gamma radiation emitted by the rocks surrounding the borehole. The American Petroleum Institute (API) gamma-ray unit is used in this report. The natural-gamma and electromagnetic logs were collected by several different geophysical logging companies between 1964 and 1993 and are reported as calibrated values; however, no calibration documentation was available to verify their accuracy. Shale and clay units commonly emit higher natural-gamma radiation than do sandstone units (Keys and MacCarthy, 1990), but subsurface lithology can not be determined solely on the basis of natural-gamma radiation.

Electromagnetic-induction logs record the electrical conductivity of the rocks and water surrounding the borehole. Electrical conductivity is affected by the porosity, permeability, and clay content of rocks, and by the dissolvedsolids concentration of the water within the rocks.

\section{Drilling Logs}

Descriptions of drill cuttings by drillers and geologists were used to determine lithologic and stratigraphic information about the subsurface units, the altitudes of the units, and the relative water levels within the $\mathrm{D}$ and $\mathrm{N}$ aquifers. Drilling logs included both lithologic and stratigraphic descriptions. Lithologic and stratigraphic descriptions of the subsurface units were used to support borehole-geophysical data, determine depths to the tops of the Carmel Formation and Navajo Sandstone, provide data for sites where geophysical data were unavailable, and develop a thickness map of the Carmel Formation.

\section{Lithology and Thickness of the Carmel Formation as Related to Ground-Water Leakage}

Borehole-geophysical data and geologic descriptions of drilling logs examined during this study indicate that the Carmel Formation consists of siltstones in the southern part of the confined area of the $\mathrm{N}$ aquifer where leakage was detected in previous studies. The formation is thinner in the southern areas where leakage has been detected than in the northern areas where leakage has not been detected (fig. 3). 


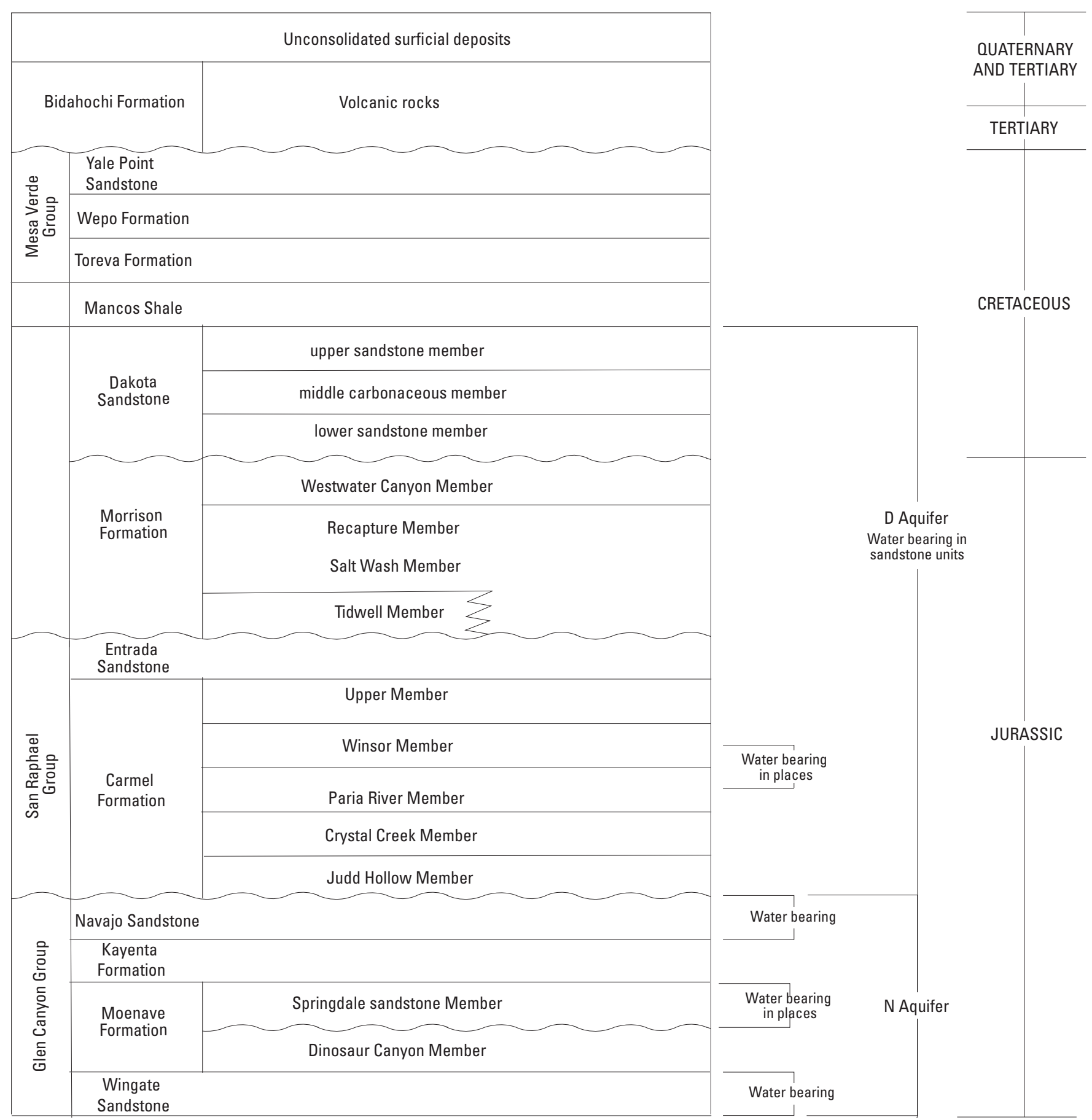

Note: Members and units of formations underlying rocks of the $\mathrm{N}$ aquifer are not shown.
Geology from Harshbarger and others, 1957; Cooley and others, 1969; Irwin and others, 1971; 0' Sullivan and others, 1972; Peterson and Pipiringos, 1979; Peterson, 1988; and Dubiel, 1989

Figure 2. Rock formations and hydrogeologic units of the $\mathrm{D}$ and $\mathrm{N}$ aquifers, Black Mesa, Arizona. 


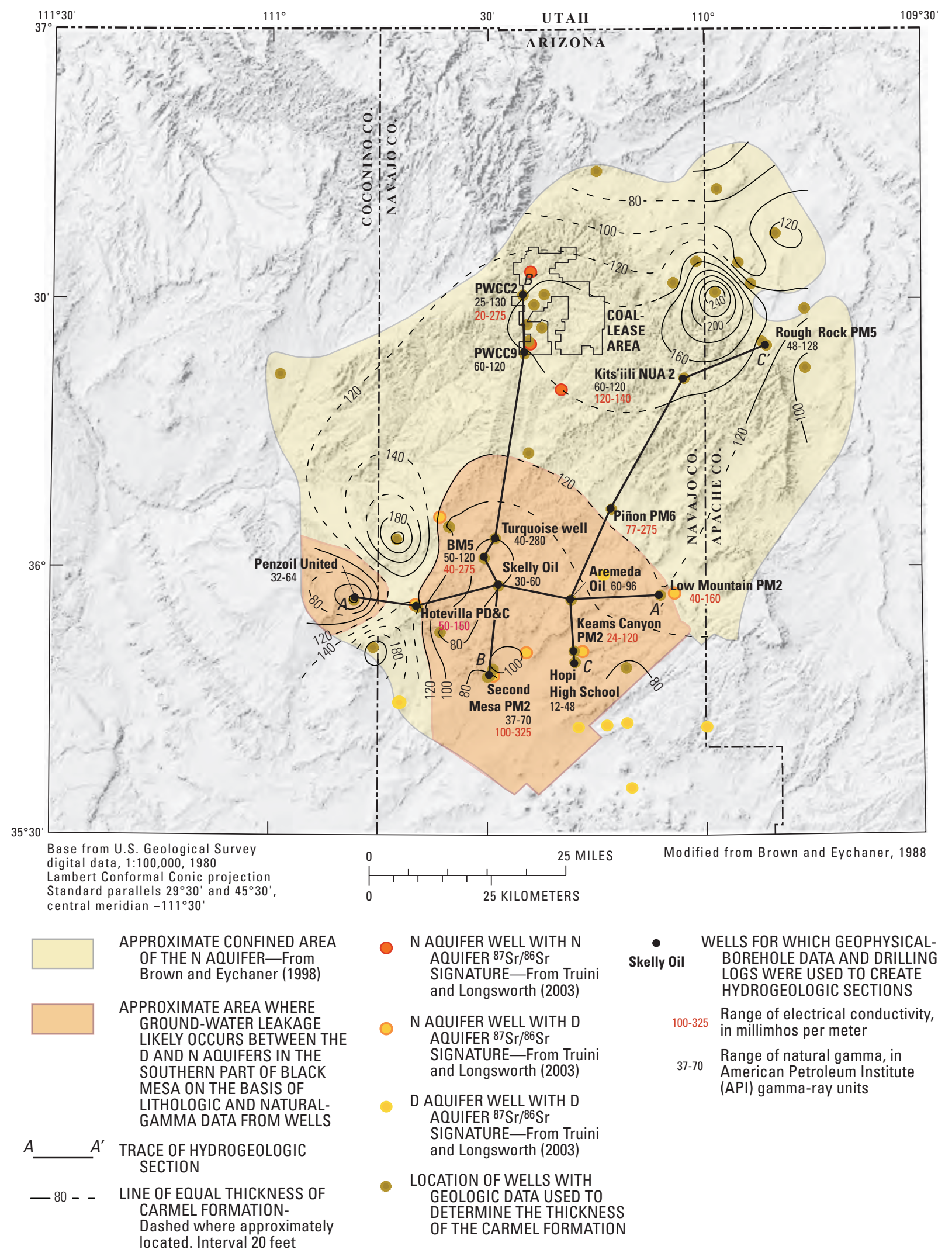

Figure 3. Thickness of the Carmel Formation, ranges of natural gamma and electrical conductivity from boreholegeophysical logs, and relative ${ }^{87} \mathrm{Sr} /{ }^{86} \mathrm{Sr}$ signatures, Black Mesa, Arizona. 
Borehole-geophysical logs were useful in differentiating sediment types and delineating the contact between the Carmel Formation and the underlying Navajo Sandstone. Naturalgamma intensities for fine-grained sediments of the Carmel Formation generally exceeded 50 API gamma-ray units, and intensities for the coarser grained Navajo Sandstone generally were less than 25 API gamma-ray units (pl. 1). Intensities generally were lower for sediments in the southern part of the study area and increased to the north and northwest (pl. 1 and fig. 3). The logs show that the Carmel could grade from a sandy siltstone in the southern part of the area to a clayey siltstone in the northern part.

Electrical conductivity from the electromagneticinduction logs was more than 200 millimohs per meter for the Carmel Formation and less than 50 millimohs per meter for the Navajo Sandstone (pl. 1). The logs were useful in distinguishing between the sediments of the Carmel Formation and those of the Navajo Sandstone, and in determining the thickness of the Carmel (fig. 3 and pl. 1).

Areas where the Carmel Formation is $120 \mathrm{ft}$ or less coincide with areas where ${ }^{87} \mathrm{Sr} /{ }^{86} \mathrm{Sr}$ values and major-ion data for ground water indicate that $\mathrm{D}$ aquifer water has mixed with $\mathrm{N}$ aquifer water as a result of leakage (Truini and Longsworth, 2003; fig. 3). In the southern part of the area where the $\mathrm{N}$ aquifer is under confined conditions, the thickness of the Carmel Formation is about $50 \mathrm{ft}$ near BM5 well, $100 \mathrm{ft}$ near the Hopi High School and Keams Canyon PM 2 wells, $50 \mathrm{ft}$ near Second Mesa PM2 well, and $150 \mathrm{ft}$ near Hotevilla P D \& $\mathrm{C}$ well (fig. 3). In the northern part of Black Mesa, the Carmel is $150 \mathrm{ft}$ thick near the Peabody Western Coal Company wells and 160 to more than $250 \mathrm{ft}$ thick northeast of Kits'iili.

Information derived from geophysical-borehole logs and geologic descriptions of drilling logs indicate that the thickness and lithology of the Carmel Formation are factors in ground-water leakage between the $\mathrm{D}$ and $\mathrm{N}$ aquifers. Additional geophysical-borehole data from existing and new wells and cuttings analysis from new wells could be used to better delineate leakage on the basis of an improved knowledge of the thickness and lithology of the Carmel.

\section{Selected References}

Blakey, R.C., 1989, Triassic and Jurassic geology of the southern Colorado Plateau, in Jenney, J.P., and Reynolds, S.J., eds., Geologic evolution of Arizona: Arizona Geological Society Digest 17, p. 369-396.

Blakey, R.C., Peterson, F., Caputo, M.V., Geesman, R.C., and Vorheeses, B.J., 1983, Paleogeography of Middle Jurassic continental shoreline, and shallow marine sedimentation, southern Utah, in Reynolds, M.W., and Dolly, E.D., eds., Mesozoic paleogeography of the west-central U.S.: Denver, Society of Economic Paleontologist and Mineralogist, Rocky Mountain Section, p. 77-100.
Brown, J.G., and Eychaner, J.H., 1988, Simulation of five ground-water withdrawal projections for the Black Mesa area, Navajo and Hopi Indian Reservations, Arizona: U.S. Geological Survey Water-Resources Investigations Report 88-4000, $51 \mathrm{p}$.

Cooley, M.E., Harshbarger, J.W., Akers, J.P., and Hardt, W.F., 1969, Regional hydrogeology of the Navajo and Hopi Indian Reservations, Arizona, New Mexico, and Utah: U.S. Geological Survey Professional Paper 521-A, 61 p.

Dubiel, R.F., 1989, Sedimentology and revised nomenclature for the upper part of the upper Triassic Chinle Formation and the lower Jurassic Wingate Sandstone, northwestern New Mexico and northeastern Arizona, in Anderson, O.J., Lucas, S.G., Love, D.W., and Cather, S.M., eds., Southeastern Colorado Plateau: New Mexico Geological Society Fortieth Annual Field Conference, September 28-October 1, 1989, p. 213-223.

Eychaner, J.H., 1983, Geohydrology and effects of water use in the Black Mesa area, Navajo and Hopi Indian Reservations, Arizona: U.S. Geological Survey WaterSupply Paper 2201, 26 p.

Geeseman, R.C., 1979, Sedimentary facies of the Carmel Formation, southeastern Utah: Flagstaff, Northern Arizona University, unpublished master's thesis, $135 \mathrm{p}$.

GeoTrans Inc., 1993, Investigation of the N- and D- aquifer geochemistry and flow characteristics using major ion and isotopic chemistry, petrography, rock stress analysis, and dendrochronology in the Black Mesa area, Arizona: Prepared for Peabody Coal Company, project No. 8369.400.

Harshbarger, J.W., Repenning, C.A., and Irwin, J.H., 1957, Stratigraphy of the uppermost Triassic and the Jurassic rocks of the Navajo country: U.S. Geological Survey Professional Paper 291, 74 p.

Irwin, J.H., Stevens, P.R., and Cooley, M.E., 1971, Geology of the Paleozoic rocks, Navajo and Hopi Indian Reservations, Arizona, New Mexico, and Utah: U.S. Geological Survey Professional Paper 521-C, $32 \mathrm{p}$.

Jenney, J.P. and Reynolds, S.J., 1989, Geologic evolution of Arizona: Tucson, Arizona Geological Society Digest, p. 369-396.

Keys, W. Scott, 1988, Borehole geophysics applied to groundwater hydrology: U.S. Geological Survey Open-File Report 87-539, p. 130 and 155.

Keys and McCarthy, 1990, Application of borehole geophysics to water-resources investigations: Techniques of WaterResources Investigations of the United States Geological Survey, book 2, chap. E1, 126 p. 
Lopes, T.J., and Hoffmann, J.P., 1997, Geochemical analyses of ground-water ages, recharge rates, and hydraulic conductivity of the N Aquifer, Black Mesa area, Arizona: U.S. Geological Survey Water-Resources Investigations Report 96-4190, 42 p.

Middleton, L.T. and Blakey, R.C., 1983, Sedimentologic processes and controls on the intertonguing of the fluvial Kayenta and eolian Navajo Sandstone, northern Arizona and southern Utah, in Brookfield, M.E., and Ahlbrant, T.S., eds., Eolian sediments and processes: Amsterdam, Elsevier, Developments in Sedimentology, no. 38, p. 613-634.

O'Sullivan, R.B., Repenning, C.A., Beaumont, E.C., and Page, H.G., 1972, Stratigraphy of the Cretaceous rocks and the Tertiary Ojo Alamo Sandstone, Navajo and Hopi Indian Reservations, Arizona, New Mexico, and Utah: U.S. Geological Survey Professional Paper 521-B, 34 p.

Peterson, Fred, 1988, Stratigraphy and nomenclature of Middle and Upper Jurassic rocks, western Colorado Plateau, Utah and Arizona, in Revisions to stratigraphic nomenclature of Jurassic and Cretaceous rocks of the Colorado Plateau: U.S. Geological Survey Bulletin 1633-B, p. 13-56.

Peterson, Fred, and Pipiringos, G.N., 1979, Stratigraphic relations of the Navajo Sandstone to Middle Jurassic formations, southern Utah and northern Arizona: U.S. Geological Survey Professional Paper 1035-B, 43 p.

Robinson, S. Edwin and Coruth, Cahit, 1988, Basic exploration of geophysics: John Wiley and Sons, New York, p. 309-444.

Truini, Margot, and Longsworth, S.A., 2003, Hydrogeology of the D aquifer and movement and ages of ground water determined from geochemical and isotopic analyses, Black Mesa area, northeastern Arizona: U.S. Geological Survey Water-Resources Investigations Report 03-4189, 38 p.

U.S. Environmental Protection Agency, 2005, 2004 Edition of the Drinking Water Standards and Health Advisories: U.S. Environmental Protection agency, accessed August 15, 2005 at http://epa.gov/waterscience/criteria/drinking/standards/ dwstandards.pdf.

Vorrheese, B. J., 1978, Stratigraphy and facies of the lower Carmel Formation (Middle Jurassic), southwestern Utah: Flagstaff, Northern Arizona University, unpublished master's thesis, $161 \mathrm{p}$. 


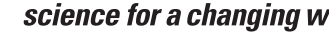

Section $A-A$
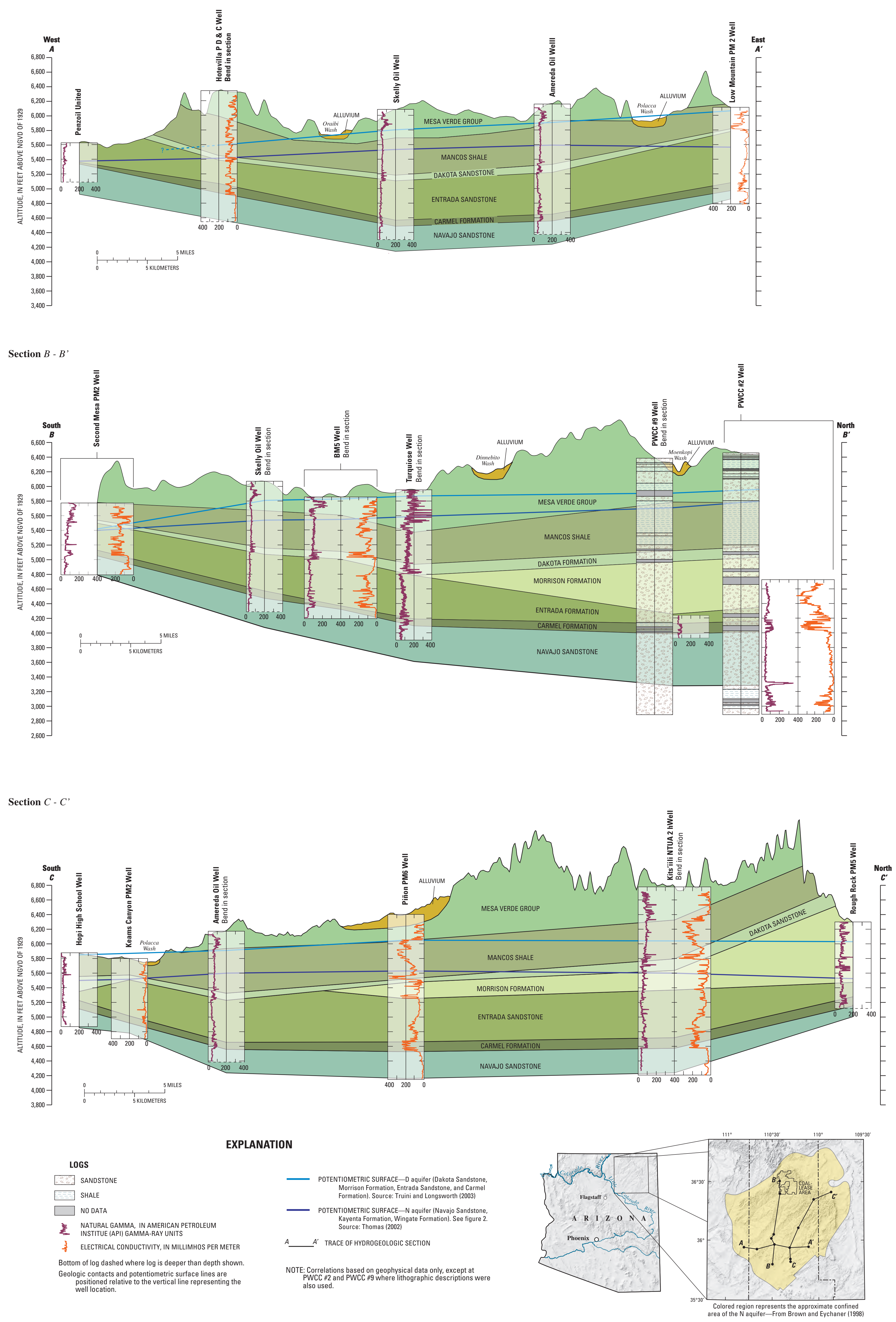

Hydrogeologic sections showing correlations of units of the $D$ and $N$ aquifers from borehole-geophysical data and lithologic descriptions, Black Mesa, Arizona 